regionalism is fully accepted by the Government although it is realized that it may not always be possible to provide in any one college all the courses which students might desire. He thought that there should be little difficulty in making satisfactory arrangements for those students living outside the boundary of the local authority responsible for the college, and he confirmed the Ministry's recognition of the importance of technical and technological development and the vital part which rescarch plays in such development. Nevertheless, it was apparent from Mr. Pickthorn's reply and Mr. William Wells's opening speech that there is little prospect of getting an effective central policy for technical education while it remains under the control of local education authorities, and indeed of the Ministry of Education. The need was again clearly demonstrated for placing the responsibility for higher technological education fairly and squarely on one body closely concerned with university education, such as the University Grants Committee.

\section{Joint Commission on Electron Microscopy}

By agreement with the International Council of Scientific Unions, a Joint Commission on Electron Microscopy has been formed, which is made up of four participating International Unions, represented as follows : International Union of Pure and Applied Chemistry, Dr. A. S. McFarlane (Great Britain) and Prof. R. Signer (Switzerland) ; International Union of Biological Sciences, Prof. L. Bugnard (France), Prof. Irene Manton (Great Britain) and Dr. F. O. Schmitt (United States); International Union of Crystallography, Dr. R. W. G. Wyckoff (United States); International Union of Pure and Applied Physics (the parent Union of the new Commission), Dr. G. Dupouy (France), J. B. le Poole (Netherlands) and Mr. F. W. Cuckow (Great Britain). The Joint Commission is now organizing an international conference on clectron microscopy which will be held at the London School of Hygiene and Tropical Medicine during July 6-9, 1954; further details of the conference will be announced later. All communications regarding the Joint Commission should be addressed to Mr. F. W. Cuckow, Provisional Secretary, Joint Commission on Electron Microscopy, Institute of Cancer Research, Royal Cancer Hospital, London, S.W.3.

\section{East African Industrial Research Board : Report for 1952}

THE tenth annual report of the East African Industrial Research Board covers the year ended December 31, 1952 (pp. 20. Nairobi : East African High Commission, 1953). Full agreement between the East African Governments on the future of research has not yet been reached, and until a permanent organization is established, activities cannot be extended to include civil engineering or metallurgical investigations on the scale desirable. Investigations on hecogenin were concentrated on the pilot-scale production of material containing crude hecogenin from waste obtained in the dry decortication of sisal, and the National Research Development Corporation and the Medical Research Council were supplied with material for use in the synthesis of cortisone. The possibility of separating the niobium mineral pyrochlore from an apatite concentrate obtained from Sukulu soil is being investigated. Triple superphosphate has already been obtained satisfactorily from Sukulu apatite. Investi- gations of the most economical method of binding fine kyanite for heating in a rotary kiln indicate that pelletizing the powder with molasses gives the best results. A clay deposit has been found near Nairobi from which a satisfactory drain-pipe body can be prepared that will take a lava glaze. Cement clinker giving satisfactory strength tests has been prepared from a mixture of four clays when the interior of a stationary oil-fired kiln was modified so that it was more like a muffle furnace. The study of the fermentation of vegetable matter, such as sisal and papyrus, has been commenced, with the objective of utilizing methane from such fermentation for drying, for the generation of power or as a motor fuel. A full account of preliminary experiments leading to work with a semi-pilot scale digestor on the gaseous fermentation of sisal waste is appended to the report. The gas obtained consists chiefly of carbon dioxide and methane in the ratio $2: 3$ by volume. Other appendixes deal with the purification of diatomite obtained from deposits in Kenya and with methods of improving the setting qualities of plaster of paris obtained by calcining local gypsum.

\section{Max Planck Association for the Advancement of Science}

IN 1945 the German Research Institute, BerlinDahlem, was set up, incorporating the organization formerly known as the Kaiser Wilhelm Institute and Research Establishment. The German Research Institute has now been dissolved, with effect from July 1, and has been joined to the Max Planck Association for the Advancement of Science (headquarters: 10 Bunsenstrasse, Göttingen). The following institutions in Berlin-Dahlem (with number and name of street as shown, followed by the name of the director in brackets) have therefore been taken over by the Max Planck Association: Max Planck Institute for Comparative Genetics and Congenital Pathology, 26-28 Ehrenbergstrasse (Prof. Hans Nachtsheim), and the Department of Tissue Research, 9 Garystrasse (Prof. (Mrs.) Else Knake) ; Fritz Haber Institute of the Max Planck Association, 4-6 Faradayweg (Prof. Max von Laue); Berlin Department of the Max Planck Institute for Foreign Public Law and International Law, 1 Boltzmannstrasse (Dr. Erich Kraske); Max Planck Institute for Cell Physiology, 32 Garystrasse (Prof. Otto Warburg); Research Establishment for the Recording of Plant Cultures in the Max Planck Association, 16 Faradayweg (Prof. (Mrs.) Elisabeth Schiemann); Research Establishment for Micromorphology in the Max Planck Association, 16 Faradayweg (Dr. J. G. Helmcke).

\section{Stranded Whales and Turtles}

THE systematic reporting of stranded whales, dolphins and porpoises to the British Museum (Natural History) came into operation in 1913. The keeper of zoology at that time, Sir Sidney F. Harmer, was responsible for starting the scheme, and with the willing co-operation of the Board of Trade and other competent authorities, a valuable supply of material and data has since been sent to the Museum. Up to the present, 1,041 specific identifications of stranded cetaceans have been made. As a result, certain species thought to be rare are found to be commoner than previously believed, and two new species have been added to the British list. Receivers of wreck and the officers of the Coastguard Service have 